\title{
THE ROLE OF INNOVATION IN CONTEMPORARY BUSINESS MODELS - THE COGNITIVE-EMPIRICAL STUDY
}

\author{
MAŁGORZATA BROJAK-TRZASKOWSKA
}

University of Szczecin, Faculty of Management and Economics of Services, POLAND

e-mail: malgorzata.brojak@wzieu.pl

RECEIVED
ACCEPTED
JEL
CLASSIFICATION

KEYWORDS

ABSTRACT
10 December 2018

28 December 2018

M21, M29, 012, 031

business economics, innovations, business models, innovative business models - business models based on innovations

The paper initiated a scientific discussion on the importance of innovations in the development and implementation process of modern business models in order to deliver real benefits by this virtue. The structure of work consists of four following parts, which is subjected to research intentions. The first is the introducing part, which is targeted at formulating a research problem and justifying undertaking the subject research. The second is the cognitive part, which includes a synthesis of theoretical contents on subjects of research, based on critical literature studies. The third part has an empirical dimension, which verifies developed theoretical assumptions based on own research findings. The fourth is the summary part, which recapitulates research studies, i.e. presents main research conclusions. Although the empirical research concerns the exemplification of undertakings in the tourism sector, due to a considerable heterogeneity of research sample (diversity of accommodation establishments, eating places, entities providing associated services, such as recreation, cultural, information, marketing and organisational services as well as transport undertakings and trading companies) obtained results can be generalised in relation to Polish service companies. Such an approach to research is justified not only by the diversity of entities surveyed having regard to the nature of business in subjective terms but also by their objective inhomogeneity, i.e. due to sector and ownership form, organisational formand size of company.

\section{Introduction}

The present-day management conditions determined by competitive pressures, growing quality requirements, technical and organisational progress and reduction of product and service life cycles make that - apart from mentioned phenomena - the questions of innovativeness of undertakings become increasingly important. This innovativeness should be implemented on an ongoing basis and only as a complement - as ad hoc actions based 
on innovations resulting from a brainwave or intuition. In addition, development activities based on creation and implementation of innovative projects should be reflected in management systems of economic operators, i.e. both in action strategies, tactical plans, operational plans and developed plans, in particular, in effectively implemented business models.

On the basis of the above assumptions, the answer to the following question is deemed the main objective of the paper: What role do innovations play in modern business models aimed at boosting growth and development of businesses, thus growth of their competitiveness? Justification for undertaking this subject is also its topicality and importance for social and economic development from different management levels.

The explanation of research problem is based on theoretical-cognitive and empirical research. It is worth noting that the inferential dimension of performed theoretical studies resulted in formulating certain theorems relevant from the point of view of theory and economic practice as well.

\section{Methods of research}

A research approach, based on wide literature studies, in particular their critical analysis, is used in the course of performed theoretical works, as well as on this basis - generalising inference - the obtained results of cognitive research are applied to Polish enterprises.

Results of own surveys carried out in 2016 among operators representing the tourism sector are used in the empirical part. Factual materials on subjects of research are analysed in this part. A representative research sample ( 1,508 business units) was selected by means of a simple random process in the first stage of research. 254 correctly completed surveys were returned which made that basic statistical parameters amounted accordingly to: level of confidence -0.94 , however, statistical error increased by $1 \%$ compared to pre-defined error of $5 \%$. The results presented in the paper complement a wider a scientific and research programme completed in 2018. Detailed research characterisation is included in the monograph, entitled Innovative business models in economic tourism operators in which the research approach by specific stages, i.e. starting from an initial phase linked to research design (conceptualisation stage) through proper implementation, inference and verification phase, to concept phase, is described. Importantly, the statistical population surveyed was concretised as well as - adequately to a research procedure - statistical statement, sample method and technique were selected and statistically justified sample size was determined in the conceptualisation stage (Brojak-Trzaskowska, 2018, pp. 137-144).

\section{The place of innovation in business models - results of theoretical studies}

At the present time, innovations are of common interest, i.e. interest of businessmen, politicians, representatives of different non-economic organisations and academics, including those ones who connect theoretical studies with pragmatic research demonstrating a high level of application. In the field of science innovations are objects of research within technical, physical and chemical science, humanities and social science as well as biological, agricultural, medical and other sciences. To some extent this is an implication of the rank of innovations in almost every aspect of human life, both in the social, cultural, political and economic area.

A review of the research literature leads to the conclusion that the importance of business models for achieving a market success by enterprises is steadily increasing. These are most often innovative business models, i.e. concepts of business function and growth based on innovation development (acquisition) and diffusion. 
This is confirmed, inter alia, by the fact that 11 from among 27 companies from the Fortune 500 list were successful due to implementation of business model based on innovative activities (Johnson, Christensen, Kagermann, 2008, pp. 50-59).

Apart from previously mentioned researches, questions of innovation in developing business models are underlined, inter alia, by G. Hamel, M. Trapp, M.W. Johnson, E.J. Altman and others. G. Hamel, in his considerations, depends on the potential of profit created by effectiveness, originality, internal consistency and ingenuity. In this context the business model is based on introduction of innovations (in particular, radical innovations) in all areas of organisation functions, however, it is essential to integrate links between individual components of this model (Hamel, 2002, pp. 73-74; Trapp, 2013, p. 16). Attention must be paid to the need to implement "innovative innovations" and the fact that in case of innovations in the management area, in principle, we deal with gradual changes. Dynamic changes in environments and companies themselves make that it is necessary to create socalled "agile" organisations based on innovativeness and innovative business models. The presented approach reflects the concept of Agil Management (Denning, 2018, pp. 103-107). It can be added that features of development projects, such as ingenuity, originality in the context of novelty of implemented changes, as well as economic viability are inherent attributes of innovations.

This conclusion is universal, i.e. it can be used in the entire economic system, thus, in every company, regardless of its legal form, scale of operation or other classification criteria. Break-through innovations may not always be key to development and growth of a specific entity. In certain cases the success may be founded on imitative innovations but of high degree of novelty of implemented changes from the point of view of implementing entity, however, product innovations themselves are not enough to ensure conditions for survival and development of companies. Innovations must be viewed as a whole, in strategies as well as in business models designed on the basis of key resources and processes.

Modern business models require structuring a process of design and offering of products covering customers' unmet needs and expectations or coordinating a process of design and offering of new-market-centred products. Such projects include three stages (Anthony, Johnson, Sinfield, Altman, 2008, p. 149; Johnson, 2010, pp. 3-20):

1. Incubation, i.e. a process of identification of key areas jeopardising the success of a specific entity. This stage includes also testing creative proposals. During incubation of a new model, attention should be given to integration of all elements which are of major importance for a customer.

2. Acceleration, which means intensification of experiments, standardisation and monitoring of processes laying down new rules in business.

3. Change, which is identified with making a decision on reintegrating previous activities, i.e. including a new "core" to the existing structure or even creating a separate entity.

In the development and implementation process of business model, innovation should be considered in the context of its uniqueness, originality, usability - innovation should contribute to improve functionality, decrease in costs, increase in margin of profit or their specific combination (the first cognitive context). In addition, innovation should be considered as regards a specific method because it is a process that takes place somewhere in a company or in someone's mind (the second cognitive context). The last context of innovation refers to the outcome because innovation results in a new concept, product, strategy or specific process (Hitt, Duane Ireland, Hoskisson, 2015, pp. 27-29). 
In the development and implementation process of business model, it is important to clarify if innovations are connected with a specific model or these are fragmented and rather represent its component part. In the first case it is an innovative business model, however, in the other case we deal with innovations as one of structural elements of this model.

It is proven that both innovations and customers are essential components of business models. There are two forms of dependence between innovations and customers. The first form is based on creating innovations by customers, but the other one assumes creating innovations for consumers (Bombol, 2017).

By organising the tools of innovative operations useful during the discussed structuring process of subject activities (Eveleens, 2010, pp. 112-121; Lopes et al., 2010) it should be mentioned their following groups:

- knowledge management instruments, including instruments for mapping and audit of knowledge resources (Huizenga, 2014, pp. 5-20),

- techniques for market intelligence - search for new technologies, business analysis, network tools for development of project teams, chains of supply,

- instruments for stimulating employees' creativity - brainstorming, SCAMPER methodology, improvement technique for processes, e.g. comparative analyses,

- instruments concerning projects - single projects and entire portfolios of projects, including computeraided design (Hidalgo, Albors, 2008, pp. 113-127).

The previous scientific reflections on subjects of research allow for the conclusion that modern business models should take account of systematic introduction of innovations in business activities, i.e. both dissemination of new products, services, organisation methods of operations and business processes as well as improvement of the status quo, mainly through triggering human creativity, stimulating divergence thinking and simultaneously non-schematic measures, courage in action, i.e. taking risks while respecting the classical principles of responsibility at the same time, even if a part of duties and powers is delegated.

Although, from the formal point of view, the innovative business model has not yet achieved the status of scientific company management method, but, for sure, it constitutes a logic way of its operation which, consistently applied in practice, contributes to achieving determined objectives, including, to generating values through implementation of innovations. It forms a set of useful but not only postulatory assumptions, what is essential, adequate to processes occurring in the economic reality (Brojak-Trzaskowska, 2018, pp. 66-67).

\section{The place of innovation in business models - pesults of pragmatical studies}

The results of empirical research, both in reference to innovations (Brojak-Trzaskowska, 2012, pp. 189-194) and innovative business models (Brojak-Trzaskowska, 2018, pp. 197-223) allow for the formulation of following scientific syntheses:

1. Innovativeness of Polish service companies measured by the number of implemented innovations and percentage of innovative enterprises increases, e.g. the results of the survey from 2016 showed that in case of the entire population surveyed $71 \%$ of respondents might be considered as innovative entities.

2. In the subpopulation of companies developing business models (so called active companies $-P_{A}$ ) a share of entities introducing innovations in the total number of undertakings surveyed was formed at a high level and amounted almost to $92 \%$, however, in the subpopulation of companies which did not develop such models (so called passive companies $-P_{B}$ ) $-28 \%$. This result indicates the rank of innovations in 
modern undertakings as well as it confirms the correlation between implementation of innovations and development of business models.

3. In the entire population surveyed $(n=254)$ there is noted an advantage of innovative entities over these ones which do not implement innovations at all. This phenomenon is characteristic of almost every entity surveyed, regardless of its legal form and size, therefore, in this cognitive context it is a favourable situation. We deal with an exception in case of recreation and restaurant services - taking account of a criterion of service activities - i.e. with a negative assessment of innovativeness.

4. Results of innovativeness research by administrative division of Poland show that the most favourable situation is characteristic of Mazowieckie Voivodhsip where it is noted the highest value of difference between innovative companies and entities which do not initiate such activities (+16). At the same time, it is noted that Pomorskie Voivodhsip has the worst result in terms of the size surveyed (-4). In addition, taking account of the impact of a company, the businesses functioning on international markets (+46) and on a domestic market $(+30)$ receive the highest score, however, locally operating entities are assessed negatively $(-2)$.

5. Due to the analysis of the importance of innovations in business models formed by the companies from the subpopulation $\mathrm{P}_{\mathrm{A}}$ it is concluded that in case of:

a) entities treating innovations as one of key elements of business model the following classification enterprise categories are dominant: public limited liability companies ( $23 \%$ of total positive answers), small enterprises (every third indication), complex service of tourists $(50 \%)$, private sector $(84.6 \%)$, entities in Mazowieckie and Podkarpackie regions (in total 26\%) and entities serving international markets (38\%) and domestic market (36\%);

b) respondents stating that innovations are not an important element of business model architecture there is noted an advantage of limited companies ( $29 \%$ of answers), SME sector $(71 \%)$, entities providing complex tourist services (35.7\%), private sector (71.4\%), including entities of domestic ownership (35.7\%) and mixed ownership (28.6\%), companies in Pomorskie and Ślaskie regions (in total $43 \%$ of indications) as well as entities serving a countrywide market (35.8\%);

c) respondents treating innovations on equal terms with other structural elements of business model the main role is played by limited companies (32.3\% of indications), medium-sized entities (41.9\%), complex tourist services and so-called other services (in total 58\%), private sector enterprises (90.3\%), entities located in Pomorze Zachodnie, Mazowsze, Warmia and Mazury regions (in total $23 \%$ ) and international entities (42\%).

6. When analysing the structure of innovation there is concluded that $33 \%$ of total indications is accounted for service innovations (introduction of new or improved services), however, 20\% for process innovations (changes in service provision methods, creation of new cooperation platform) and the same value for marketing innovations, e.g. initiated in order to gain a new customer base or to increase a share in the present market, however, $11 \%$ is accounted for organisational innovations.

\section{Conclusions}

Innovations should play a particularly role in current and prospective business activities. At the same time, owners, management, employees and other stakeholders should be aware that innovative initiatives should be 
of a multi-facetted nature, i.e. these should concern not only typical product, technical and technological but marketing and organisational aspects as well. In addition, they should take account of corporate social responsibility objectives and meet the general criteria of return on investment at the same time.

The complexity of innovation processes as well as turbulent external and internal changes impose the need to organise innovative activities. Furthermore, mentioned exogenous and endogenous transformations make that undertakings - typically, of a limited unit development potential - should join systems of „open” innovations, should engage in innovative cooperation as part of integrated innovation networks.

The creation of values for customers and development of sustainable cooperation platforms based on different (physical, financial and non-material, including information) flows should be the pillars of modern business models. Apart from the creation of values for customers, great importance is given to the development of value for the enterprise itself and other groups of interest.

\section{References}

Anthony, S., Johnson, M.W., Sinfield, J.V., Altman, E.J. (2008). The Innovator's Guide to Growth: Putting Disruptive Innovation to Work. Boston: Harvard Business Press.

Bombol, M. (2017). Enterprises with breakthrough innovations. Appearance at the 8th Scientific Conference from the Enterprise in the Global Economy Cycle. Warszawa: SGH.

Brojak-Trzaskowska, M. (2012). Determinanty innowacyjnego rozwoju przedsiębiorstw na przykładzie wybranych rodzajów usług. Szczecin: Wydawnictwo Naukowe Uniwersytetu Szczecińskiego.

Brojak-Trzaskowska, M. (2018). Innowacyjne modele biznesu w podmiotach gospodarczych turystyki. Szczecin: Wydawnictwo Naukowe Uniwersytetu Szczecińskiego.

Denning, S. (2018). The Age of Agile. How Smart Companies Are Transforming the Way Work Gets Done. New York: AMACON, American Management Association.

Eveleens, C. (2010). Innovation management: a literature review of innovation process models and their implications. Working Paper HAN University of Applied Sciences, 23.

Hamel, G. (2002). Leading the Revolution. Boston: Harvard Business School Press.

Hidalgo, A., Albors, J. (2008). Innovation management techniques and tools: a review from theory and practice. R\&D Management, 38 (2), 113-127.

Hitt, M.A., Duane Ireland, R., Hoskisson, R.E. (2015). Strategic Management: Competitiveness and Globalization: Concepts and Cases. South Melbourne: Victoria Cengage Learning.

Huizenga, E. (2014). The Knowledge Enterprise. Innovation Lessons from Industry Leaders. Series on Technology Management, 25. Johnson, M.W. (2010). Seizing the White Space: Business Model Innovation for Growth and Renewal. Boston: Harvard Business Press. Johnson, M.W., Christensen, C., Kagermann, H. (2008). Reinventing Your Business Model. Harvard Business Review, 12.

Lopes, A.P., Kissimoto, K.O., Salerno, M.S., Laurindo, F., Carvalho, M.C. (2010). Innovation management: a literature review about the evolution and the different innovation models. International Conference on Industrial Engineering and Operations Management, 9-11 July, Guimaräos Portugal.

Trapp, M. (2013). Realizing Business Model Innovation: A Strategic Approach for Business Unit Managers. Nurnberg: Springer Gabler.

Cite this article aS: Brojak-Trzaskowska, M. (2018). The role of innovation in contemporary business models - the cognitive-empirical study. European Journal of Service Management, 4 (28/2), 81-86. DOI: 10.18276/ejsm.2018.28/2-09. 